\title{
General Discussion to Paper of Mr J. T. Henshaw
}

\author{
DR P. Dollfus, Chairman
}

Mr Bernard Engler. My name is Bernard Engler and I am a lawyer, not a doctor, and I'd like to ask Mr Henshaw if he could tell us the weight of the swivel walker as applied to the large rugby player and what it now costs.

MR J. T. HENSHAW (G.B.). We are speaking now of the adult walker and obviously this is a research project so the cost is somewhat doubtful at the moment. We are expecting the parts to cost something in the order of $£$ I 50 to $£ 200$. Then it will have to be made, but I should point out that all these appliances have been made using aircraft design mass production methods and they generally go together relatively easily. What is happening with the smaller ones is that the cost of assembly is much less than the cost of the parts. As far as weight is concerned the weight varies enormously. The one that you saw walk was very much lighter than the big fellow I showed you on the film, but the weight is somewhere of the order of 16 to $22 \mathrm{lb}$. It's again aircraft design that's kept the weight down like this.

DR P. Dollfus. You showed a very interesting picture where the patient was performing archery. Can this patient really perform archery in an upright position and still have the same efficiency as she would have in a wheelchair?

MR HeNSHAw. Well, I don't think she was a proficient archer, but she certainly did do it. She was in an archery club in the Midlands and funnily enough the reason she left the club was because the other people complained of the clicking of the feet and said it put them off their concentration, so I assume that that would more or less rule it out.

DR Dollfus. It's a good thing you didn't try ball trap.

Sir Ludwig GutTmanN (G.B.). I'd like to congratulate Mr Henshaw on this work, because I consider this an advance for certain paraplegics and in particular tetraplegics to encourage their upright position. The only point I would like to ask you is this. These appliances fixed on the chest and on the hips in tetraplegics may produce pressure and I want to ask, did you have in that respect some mishaps that the people developed pressure sores, in particular the cervical cases? The second question concerns the cervical patient you demonstrated, $\mathrm{I}$ think he is a $\mathrm{C}_{7} / 8$ lesion. He is a very good archer in sitting position but I don't think that he could stand for any length of time to do a competition even in an easy round, because in these cases you have to consider that they are apt to fainting. So you will have to watch this very carefully. Don't start too early with cervical cases otherwise they might fall with the whole apparatus. I consider this apparatus particularly useful for children and your demonstration of a spina bifida child was very impressive indeed. Spina bifida children develop very easily a considerable kyphoscoliosis and the upright position of the children by walking the swivel way may be a great advantage indeed.

Professor Rossier (U.S.A.). Just one question to Professor Rabishant. We have experienced some problem, the braces you have shown are air inflated am I correct? We have experienced the problems that if it was hot outside the patient collapsed. Do you have any way to cope with the temperature problem?

DR RABISHANT (France). I would like to just mention that the inflation of the tubes is not to stabilise, its just to pinch the metallic pins. That means the inflatable tube is not responsible for the rigidity of this device, it is responsible for the adaptation of the segment and also the tube is included in the tissue shed in order to avoid the distention of the explosion of the tube in certain cases. That's the reason I don't think it is a real problem. Another point is we have a large window on the knee joint and the pelvis and it is maybe better to avoid certain vascular problems, but also to conserve the interest of the pneumatic system which is to compress the segment in order to avoid the hypotension due to the vertical status.

DR Dollfuss. It's 4 o'clock and time for tea.

I $7 / 2-C$ 